\title{
Growth performance and economics of production of cockerels fed graded levels of cassava (Manihot esculenta) grit basal diet
}

Okosun, S. E. and Eguaoje, A. S.

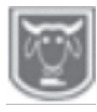

Abstract
Department of Animal Science, Faculty of Agriculture, Ambrose Alli University, Ekpoma, Edo State, Nigeria

Corresponding author:; +2347031677645, 08162931998

A sixteen week trial was conducted to assess the effects of replacing maize with cassava grit on growth performance and economics of production using 120 "Day old" Harco cockerel chickens. Four experimental cockerel starter and finisher diets were formulated. Diet 1 had $0 \%$ cassava grit (CG) while diet 2, 3 and 4 had maize replaced with cassava grit at 33.3, 66.6 and $100 \%$ replacement for maize. Chicks were randomly assigned to the four treatment diets in a completely randomized designed (CRD). Results on performance at starter phase revealed that average weekly weight gain and feed intake were significantly $(P<0.05)$ highest among birds fed 33.3\% CG. Feed conversion ratio was also significantly $(P<0.05)$ influenced while at finisher the phase average live weight, weight gain and feed conversion ratio were significantly $(P<0.05)$ higher among birds fed 33.3\% CG compared to other levels of $C G$ inclusion. Result on economics of production revealed that least cost of feed consume and cost of feed per kilogram weight gain at both phases were recorded among birds fed 100\% CG. Income and net profit were highest among birds fed 33.3\% CG. Therefore, Cassava grit can replace maize up to 33.3\% inclusion level for optimum performance and good cost returns.

Keywords: Cockerel, Cassava grit, Growth performance, economics of production, Diets

\section{Introduction}

Poultry production is one of the most popular livestock enterprises adopted by small and medium scale farmers in both rural and urban areas as it offers the highest turnover rate and quicker returns on investment outlay (Idowu et al., 2005, Afolayan et al., 2014). The benefit of poultry production is eroded by the high cost of feed and it has been well established that feed alone account for about $70 \%$ of the total cost of poultry production (Iyayi and Tewe, 1998; Fasuyi, 2005). Maize, which is the predominantly used ingredient for energy in poultry feed in Nigeria, is very costly, because of higher demand for it by humans as food and industrial purposes (Bot et al., 2013, Etuk et al., 2013). These hypothesis have activated research efforts in alternative, cheaper and readily available feed resource, notably agro industrial products, waste farm residues as well as kitchen waste as possible replacement for conventional cereal and legumes in animal feeding (Agunbiade et al., 2004 and Ajaja, 2005). Cassava root meal has been successfully used in diet of pullet(s) chick at $42 \%$ replacement level of maize without any deleterious effect on performance (Agugu and Okeke, 2005). Tuleum et al. (2005) reported that the inclusion of $50 \%$ cassava root meal/brewer yeast slurry as replacement for maize in feeding boilers has no adverse effect on the performance of broiler chick and is found to reduce the current pressure on maize and price of finished livestock farm products. Babatunde and Harnzat (2005) reported that the effect of the high cost of feed ingredient on animal production led to acute protein shortage in the diet of the citizenry. Oyewunmi (2013) reported that 


\section{Growth performance and economics of production of cockerels}

cassava grit can conviniently replace maize in layers diet without any deleterius effect on laying performance. Rafiu et al.,(2015) also reported that cassava grit can replace maize up to $40 \%$ inclusion level in broiler diet without any deleteriuos effect on performance and primal cut. Okosun and Eguaoje (2017) concluded in their report that cassava grit at $66.6 \%$ level of inclusion supplemented with 5\% level of moringa leaf meal can substitute for maize for better performance, good primal cut and optimal nutrient utilization. Cassava grit is a gelatinized product similar to pellet. This product was develops and patented in Nigeria (Patent "No. RP 16198) and the Gelatinization of this cassava product removes dustiness and improves its digestibility by poultry (Tewe, 2005). Production of cassava grits also remove a major bottleneck in cassava processing which is peeling. Their nutritive value is similar to that of cassava pellet imported into European Union (BU) from Thailand. This study was therefore set up to evaluate the growth performance and economics of production of cockerel chicken fed varying levels of cassava grit basal diet.

\section{Materials and methods \\ Location and duration of the study}

The experiment was carried out at the poultry unit of the livestock section, Teaching and Research Farm, Ambrose Alli University, Ekpoma for a period of sixteen (16) weeks. Cassava for the feeding trial was purchased from a reputable farm in Ekpoma Esan West Local Government Area of Edo State.

\section{Source and preparation of basal diet}

The woody part was chopped off, and the cassava was thoroughly washed to reduce the silica level to near zero. It was then grated without peeling screw pressed for about 48 hours to reduce the hydrogen cyanide level to the barest minimum. It was mixed with palm oil to further encapsulate the cyanide in the milled whole cassava. It was thereafter fried, air dried and bagged into product known as the Cassava grit which was used in formulating the experimental diets

Table 1: Percentage compositions of cockerel starter diets

\begin{tabular}{|c|c|c|c|c|}
\hline $\begin{array}{l}\text { Ingredients } \\
\text { Levels }\end{array}$ & $\begin{array}{r}\text { CGM }_{1} \\
0\end{array}$ & $\begin{array}{c}\mathrm{CGM}_{2} \\
33.3\end{array}$ & $\begin{array}{c}\mathrm{CGM}_{3} \\
66.6\end{array}$ & $\begin{array}{l}\mathrm{CGM}_{4} \\
100\end{array}$ \\
\hline Maize & 40.71 & 27.15 & 13.60 & 0.00 \\
\hline Cassava grit & 0.00 & 13.56 & 27.11 & 40.71 \\
\hline Soya bean meal & 29.25 & 29.84 & 32.84 & 36.33 \\
\hline Fish meal & 0.50 & 0.50 & 0.50 & 0.50 \\
\hline Wheat offal & 25.50 & 24.35 & 24.35 & 21.66 \\
\hline DCP & 2.00 & 2.00 & 2.00 & 2.00 \\
\hline Limestone & 1.20 & 1.99 & 1.99 & 1.49 \\
\hline Premix & 0.32 & 0.32 & 0.32 & 0.32 \\
\hline Salt & 0.30 & 0.30 & 0.30 & 0.30 \\
\hline Total & 100.00 & 100.00 & 100.00 & 100.00 \\
\hline \multicolumn{5}{|c|}{ Calculated analysis } \\
\hline Crude protein & 21.00 & 21.00 & 21.00 & 21.00 \\
\hline $\mathrm{ME}(\mathrm{Kcal} / \mathrm{Kg})$ & 2650 & 2650 & 2650 & 2650 \\
\hline
\end{tabular}




\section{Okosun and Eguaoje}

Table 2: Percentage compositions of cockerel finisher diets

\begin{tabular}{lllll}
\hline Ingredients & $\mathbf{C G M}_{\mathbf{1}}$ & $\mathbf{C G M}_{\mathbf{2}}$ & $\mathbf{C G M}_{\mathbf{3}}$ & $\mathbf{\mathbf { C G M } _ { \mathbf { 4 } }}$ \\
Levels & $\mathbf{0}$ & $\mathbf{3 3 . 3}$ & $\mathbf{6 6 . 6}$ & $\mathbf{1 0 0}$ \\
\hline Maize & 22.53 & 15.02 & 7.51 & 0.00 \\
Cassava grit & 0.00 & 7.51 & 15.02 & 22.53 \\
Soya bean meal & 16.56 & 16.45 & 16.94 & 18.06 \\
Palm oil & 0.00 & 0.00 & 0.00 & 0.09 \\
Wheat offal & 50.02 & 49.43 & 50.57 & 50.54 \\
DCP & 1.50 & 1.50 & 1.50 & 1.50 \\
Limestone & 3.78 & 3.64 & 2.81 & 1.51 \\
Premix & 0.30 & 0.30 & 0.30 & 0.30 \\
Salt & 0.31 & 0.31 & 0.31 & 0.31 \\
Total & 100.00 & 100.00 & 100.00 & 100.00 \\
Calculated analysis & & & & 18.00 \\
Crude protein & 18.00 & 18.00 & 18.00 & 2250 \\
ME(Kcal/Kg) & 2250 & 2250 & 2250 & \\
\hline
\end{tabular}

SBM: Soya bean meal, DCP: Dicalcium phoshate

Design and management of experimental birds

In a complete randomized design, one hundred and twenty, day old Harco cockerels were divided into four groups of thirty chicks containing three replicates of ten chicks each. The replicates were housed in floor pens measured $2.4 \mathrm{~m}^{2}$ with the floor covered with wood shavings as liter material. A plastic trough and drinker were provided in each pen. The birds were vaccinated against Gumboro at 2 and 4 weeks, Newcastle at 3 and 5 weeks, fowl cholera at 6 weeks and fowl pox disease at 9 weeks of age. Four isonitrogenous and isocaloric diets $(1,2,3$ and 4) were formulated to contain $21 \%$ and $18 \%$ crude protein and 2650 and $2250 \mathrm{kcal} / \mathrm{kg}$ Energy respectively in the chicks and grower mashes respectively (Table 1). Cassava grit was included in both the chick and grower mashes at 0.00, 33.30, 66.60 and 100\% replacement of maize in diets 1 (control), 2, 3 and 4 respectively. Feed and clean drinking water were provided ad-libitum throughout the 16 weeks of the experiment. The chick mash was fed for the first 8 weeks of age and the finisher mash for the remaining 8 weeks of the experiment.

\section{Proximate composition of basal diet}

Cassava grits was analyzed for proximate composition according to the methods of AOAC (2006). The cassava grit was again be analyzed for the residual level of hydrogen cyanide (HCN) after processing. The gross energy for cassava grit was determined using an Adiabatic Oxygen Bomb calorimeter (12149 Adiabatic calorimeter, PARR instrument Co. Illinois (USA).

Table 2: Analyzed nutrient composition of Cassava grit

\begin{tabular}{|c|c|}
\hline Nutrients (\%) & Cassava grit \\
\hline Dry matter & 88.03 \\
\hline Crude protein & 2.05 \\
\hline Crude fibre & 3.85 \\
\hline Ether extract & 2.32 \\
\hline Nitrogen free extract & 1.24 \\
\hline $\mathrm{ME}(\mathrm{Kcal} / \mathrm{Kg})$ & 78.50 \\
\hline Hydrogen cyanide & 8.50 \\
\hline
\end{tabular}




\section{Growth performance and economics of production of cockerels}

\section{Performance Study}

During the feeding trial, the cockerel chicken was weight at the beginning of the experiment (end of $4^{\text {th }}$ weeks) after the adjustment period and subsequently on a weekly basis. Weight changes and feed consumption was recorded weekly, while weight gain, feed intake, feed conversion ratio (FCR), protein efficiency ratio (PER) was estimated to assess the growth performance of the birds. Weight gain was calculated as final weight minus initial weight, feed conversion ratio (FCR) as feed intake divided by weight gain.

\section{Economics of production}

The prevailing market price of feedstuffs and the live market value of cockerel at termination of trial were used to estimate cost of feed and sales of product.

\section{Statistical analysis}

All data were subjected to analysis of variance (ANOVA) and differences between treatments and means was determined using Duncan's Multiple Range Test at 5\% level of probability. All statistical procedures were according to Steel and Torrie (1990) using SAS (1999) package.

\section{Results}

Data on the performance of cockerel chickens at the starter phase (Table 3) revealed that average weekly weight gain was significantly $(\mathrm{P}<0.05)$ influenced by the treatment diets with highest value $(1.03 \mathrm{~kg} / \mathrm{bird})$ recorded among birds fed $33.3 \%$ CG and least $(0.56 \mathrm{~kg} / \mathrm{bird})$ in those fed $100 \%$ CG. Average weekly feed intake was significantly $(\mathrm{P}<0.05)$ highest $(3.09 \mathrm{~kg} / \mathrm{bird})$ in birds fed $33.3 \% \mathrm{CG}$ and least $(2.44 \mathrm{~kg} / \mathrm{bird})$ in birds placed on diet 4 . Feed conversion ratio was significantly $(\mathrm{P}<0.05)$ higher in diet 4 with mean value of 12.56 and lowest 9.09 in birds fed the control. Protein efficiency ratio was also significantly $(\mathrm{P}<0.05)$ influenced with higher mean value of 2.23 recorded in birds fed the control though similar to those in diet 4. While PER was lowest (1.11) in birds fed diet 3. At finisher phase (Table 4), however average live weight, feed intake and weight gain were significantly $(\mathrm{P}<0.05)$ higher in birds fed $33.3 \% \mathrm{CG}$ compare to other treatment diets. Feed conversion ratio was also significantly higher $(\mathrm{P}<0.05)$ among birds fed the control (3.38) , followed by 2.60 in birds fed $33.3 \% \mathrm{CG}$ and least in birds fed $100 \% \mathrm{CG}$.

Table 3: Performanceof starter cockerel fed the dietary treatment

\begin{tabular}{|c|c|c|c|c|c|}
\hline \multirow[b]{4}{*}{ Parameters } & \multicolumn{4}{|c|}{ Inclusion levels of Cassava grit (\%) } & \multirow[b]{4}{*}{ SEM \pm} \\
\hline & $\mathbf{0}$ & 33.3 & 66.6 & 100 & \\
\hline & \multicolumn{4}{|c|}{ Diets } & \\
\hline & 1 & 2 & 3 & 4 & \\
\hline Ave. Initial weight (g/bird) & 50.03 & 50.40 & 50.00 & 50.00 & 0.04 \\
\hline Ave. Weight gain (g/bird) & 1.10 & 1.03 & 0.74 & 0.56 & 0.03 \\
\hline Ave. Weekly feed intake (g/bird) & 2.85 & 3.09 & 2.56 & 2.44 & 0.06 \\
\hline Feed conversion ratio & 9.90 & 9.52 & 12.47 & 12.56 & 1.13 \\
\hline
\end{tabular}

Table 4: performance of cockerel finisher fed experimental diet

\begin{tabular}{lccccc}
\hline & \multicolumn{3}{c}{ Inclusion levels of Cassava grit (\%) } \\
& $\mathbf{0}$ & $\mathbf{3 3 . 3}$ & $\begin{array}{c}\mathbf{6 6 . 6} \\
\text { Diets }\end{array}$ & $\mathbf{1 0 0}$ \\
Parameters & $\mathbf{1}$ & $\mathbf{2}$ & $\mathbf{3}$ & $\mathbf{4}$ & SEM \pm \\
\hline Ave. Final weight $\mathrm{K}(\mathrm{g} / \mathrm{bird})$ & $1.70^{\mathrm{b}}$ & $1.93^{\mathrm{a}}$ & $1.47^{\mathrm{c}}$ & $1.33^{\mathrm{d}}$ & 0.08 \\
Ave. Weekly weight gain $(\mathrm{Kg} / \mathrm{b})$ & $0.84^{\mathrm{ab}}$ & $0.93^{\mathrm{a}}$ & $0.73^{\mathrm{bc}}$ & $0.70^{\mathrm{c}}$ & 0.04 \\
Ave. Weekly feed intake $(\mathrm{Kg} / \mathrm{b})$ & 2.29 & $3.25^{\mathrm{a}}$ & $2.80^{\mathrm{c}}$ & $2.71^{\mathrm{c}}$ & 0.05 \\
Feed conversion ratio & 3.38 & 9.52 & 2.60 & 12.56 & 0.24 \\
\hline abcd: mean in the same row with varying superscripts differs significantly $(\mathbf{P}<\mathbf{0 . 0 5})$. & &
\end{tabular}




\section{Okosun and Eguaoje}

\section{Economics of production}

Highest average final live weight was observed in birds fed 33.3\% CG based diet and least in birds fed $100 \%$ CG. At the starter phase cost of feed consumed and cost of feed per $\mathrm{kg}$ weight gain was lowest (? 183.95/bird) in cockerel feed 100\% CG and highest (? 239.90/bird) in birds fed $66.6 \%$ CG. Cost of feed $/ \mathrm{kg}$ weight gain was lowest (? 3.43/bird) also in birds fed $100 \% \mathrm{CG}$ and highest (? 10.00/bird) in birds fed the control diet. At finisher phase, cost of feed consumed was highest (? 252.33) among birds fed $33.3 \% \mathrm{CG}$ and least (? 204.31) among birds fed 100\% CG. Cost of feed $/ \mathrm{kg}$ weight gain was least (? 14.30) among birds fed diet 4 and highest (? 23.47) in diet 2. Cost of production was least (? 798.26) in birds fed diet 4 and higher (? 844.26) among birds fed the control diet. Income and net profit was highest among birds fed $33.3 \%$ CG compare to the control and least among birds placed on $100 \% \mathrm{CG}$.

Table 5: Cost analyses of cockerel chickens fed dietary treatment

\begin{tabular}{|c|c|c|c|c|}
\hline $\begin{array}{l}\text { Ingredients } \\
\text { Levels }\end{array}$ & $\begin{array}{c}\mathrm{CGM}_{1} \\
0\end{array}$ & $\begin{array}{c}\mathrm{CGM}_{2} \\
33.3\end{array}$ & $\begin{array}{c}\mathrm{CGM}_{3} \\
66.6\end{array}$ & $\begin{array}{c}\mathrm{CGM}_{4} \\
100\end{array}$ \\
\hline Ave. Final live weight (Kg/bird) & 1.70 & 1.93 & 1.47 & 1.33 \\
\hline \multicolumn{5}{|l|}{ Starter phase } \\
\hline Cost of day old chicks (\#/bird) & 60.00 & 60.00 & 60.00 & 60.00 \\
\hline Cost of feed consumed ( $\$ /$ bird) & 226.86 & 239.90 & 197.02 & 183.95 \\
\hline Cost of feed/ Kg weight gained ( $\# /$ bird) & 10.00 & 8.20 & 5.00 & 3.43 \\
\hline \multicolumn{5}{|l|}{ Finisher phase } \\
\hline Cost of feed consumed ( $\# /$ bird) & 238.00 & 252.23 & 215.49 & 204.31 \\
\hline Cost of feed/kg weight gain ( & 20.00 & 23.47 & 15.66 & 14.30 \\
\hline Cost of production ( $\# /$ bird) & 844.26 & 802.23 & 802.23 & 798.26 \\
\hline Income & 1500 & 1500 & 1000 & 900 \\
\hline Net profit & 655.76 & 697.77 & 177.49 & 101.74 \\
\hline
\end{tabular}

\section{Discussion}

\section{Performance characteristics of cockerel chickens}

The performance of cockerel chickens in this study revealed that feeding of graded levels of cassava grit significantly $(\mathrm{P}<0.05)$ influenced the weight gain, feed intake, feed conversion ratio and protein efficiency ratio at the starter phase. On the contrary, average initial weight gain of the birds were not significantly $(\mathrm{P}>0.05)$ affected by the dietary treatments. At the finisher phase, average live weight gain and feed intake were significantly $(\mathrm{P}<0.05)$ influenced by the treatment diet while feed conversion ratio and protein efficiency ratio were not significantly $(\mathrm{P}>0.05)$ affected by the dietary treatments. The significantly
$(\mathrm{P}<0.05)$ higher weight gained by birds placed on $33.3 \%$ Cassava Grit basal diet at the starter and finishing phase compared to the other dietary treatment may be ascribed to the nutrient and energy availability and density which eventually translated to the improvement in growth rate. This is in tandem with the works of Igene and Esobhawan (2003); Oboh et al. (2004) that an increase in dietary energy increased weight gain of birds. Obsevation from this finding also agreed with Bhuiyan and iji (2013) who reported a significant variation in the weight gain of broilers fed cassava product supplemented with or without enzyme. The highest feed intake value observed among birds fed $33.3 \%$ cassava grit based diet translated to the birds having 


\section{Growth performance and economics of production of cockerels}

the highest live weight at the finisher phase. This shows that the inclusion of cassava grit at $33.3 \%$ did not negatively impact the palatability of the diets. This corroborate the finding of El- Boshey and vanderpoel (1994) and negated the report of Rafiu et al.(2015) who observed similarity in the feed intake of broiler chickens fed varying levels of cassava grit as replacement for maize. Higher feed conversion ratio recorded in birds fed 100\% cassava grit based diets could be traced to the decline in dietary energy and protein with increasing inclusion level of dietary cassava grit Rafiu et al. (2015).

\section{Economics of production}

The least cost of feed consumed and cost of feed per kilogram weight gain recorded among birds fed diet 4 could be as a result of the reduced cost of cassava grit compared to expensive maize used in formulating the control diet. It was also observed at both starter and finisher phases that cost of feed consumed reduced as the inclusion level of cassava grit increased. This observation was supported by the findings of Omoikhoje et al. (2008) on reduction in the cost of feed, cost of feed $/ \mathrm{kg}$ weight gain, cost of production and improvement in the profit margin in rabbits fed inclusion of 30 $\%$ level of unpeeled cassava waste meal in their diets. The least cost of production recorded in bird fed diet 4 could be due to the low price of cassava grit. This is lend support from the report of Nworgwu et al. (2000) who stated that there is need for dietary incorporation of unconventional feed ingredient as alternative, noncompetitive, readily available and cheap ingredients so as to reduce the cost of production and in the long run increase profit margin. The highest income and net profit recorded among birds fed 33.3\% compare to control was a pointer to the fact that the inclusion of cassava grit at $33.3 \%$ level reduced cost of production and thus translated to higher profit margin. Zahari and Alimon (2006) had earlier reported improvement in the feed efficiency through the accelerated use of local feed stuff in other to reduce high production cost thereby increasing profit.

\section{Conclusion}

It was obvious from this study that the inclusion of cassava grit in the diets of cockerel up to $33.3 \%$ replacement improved growth performance and ultimately better profit margin; therefore, cassava grit can be used to maximize profit in cockerel production.

\section{References}

A.O.A.C. 2006. Association of Official Analytical Chemist. Official method of analysis (W. Horwitz, Editor). 20th edition, Arlington VA, U.S.A.

Afolayan, M., Bawa, G. S., Sekoni, A. A., Abeke, F. O. and Daramola, S. T. 2014. Effect of inclusion level of African Locust Bean (Parkia biglobosa) Pulp on growth parameters of egg type chicken (0-20 weeks). Nigerian Journal of Animal Science, 16(1): 51-60.

Agugu, G. O. and Okeke, G. C. 2005. Effect of replacing maize with cassava root meal in the diet of pullet chicks. Proceeding of the $30^{\text {th }}$ animal conference of the Nigeria society for Animal production Pp 235-236.

Agunbiade, J. A., Adeyemi, A. O. Fashina, O. E. Bagbe, S. A. 2004. shrimps waste meal supplement of cassava product based diet fed to broiler chicken. Nigerian journal of Animal 


\section{Okosun and Eguaoje}

production 28(2): 167-173.

Ajaja, K. 2005. Effect of replacing maize with sorghum diet in diets for broilers finisher. Department of Agriculture Education College of Education Ikere Ekiti.

Babatude, B. B. and Hamzat, R. A. 2005. Effect of Feeding Graded Levels of Kolanbut Husk meal on the Performance of Cockerel. Nigeria Journal of Animal Production. 32:61-68.

Bhuiyan, M. M. and Iji, P. A. 2013. Energy Value of Cassava Products in Broiler Chicken Diets with or without Enzyme Supplementation. Br J Nutr.;99:682-690.

Bot, M. H., Bawa, G. S. and Abeke, F. O. 2013. Replacement value of maize with African locust bean (Parkia biglobosa) pulp meal on performance, haematological and carcass characteristics of broilers. Nigerian Journal of Animal Science, 15: 59-70.

El- Boushey, A. R. and Vander Poel, A. F. B. 1994. Poultry Feed from Wastde Processing and use First Ed. Chapman Acid Hall. Pp 377.

Etuk, E. B., Anopueme, B., Etuk, I. F., Ekpo, J. S., Emenalom, O. O. and Esonu, B. O. 2013. Effect of different combination levels of palm kernel cake, yam peel and plantain peel meals as partial replacement for maize in broiler starter diets. Nigerian Journal of Animal Production, 40(1): 73-78

Fasuyi, A. O. 2005. Nutritional evaluation of cassava leaf protein concentrate as alternative protein sources in rat assay. Pakistan Journal of Nutrition. 4:
$50-56$.

Fisher, C. and Boorman, K. N. 1986. Poultry and Nutritional Research. Asian Journal of Animal and Veterinary Advances, 6: 20-28.

Idowu, O. M. O., Oduwefo, A. and Eruvbetine, D. 2005 . Performance and hypocholesterlemic response of laying hens fed cassava root sievate-based diets. Nigerian journal of animal production $\mathrm{Pp}$ 215-223.

Iyayi, E. A. and Tewe, O. O. 1998. Serum total protein, Urea, and creatinine levels as indices of quality of cassava diets for pigs, Trop. Vet., 36, 59-67.

Nworgwu, F. C., egbumnko, G. W. and ogundola, F. L. (2000). Performance and nitrogen utilization of broiler chicken fed full fat soya beans. Tropical animal production investigation, 3(1):75-87.

Omoikhoje, S. O., Bamgbose, A. M. and A r u n a, M . B . 2008 . Replacement value of unpeeled cassava root meal for maize in broiler diets. Nigerian journal of animal production, 35(1): 63 68.

Okosun, S. E. and Eguaoje, S. A. 2017. Growth Performance, Carcass Response And Cost Benefit Analysis Of Cockerel Fed Graded Levels Of Cassava (Manihot Esculenta) Grit Supplemented With Moringa (Moringa Oleifera) Leaf Meal. A $\mathrm{n} \mathrm{i} \mathrm{m} \mathrm{a} 1 \mathrm{R}$ e s e a $\mathrm{c} \mathrm{h}$ International.14(1):2619-2628.

Oyewunmi, S. O. 2013. Performance, egg quality and haematological 


\section{Growth performance and economics of production of cockerels}

Characteristics of layers fed cas a a grit Meal. Transnational Journal of Science and Technology.Vol 3(8):50-59

Rafiu, T. A., Giwa, H. O., Babatunde, G. M., Jokodola, O. A. (2015). Effect of the replacement of maize with varying levels of cassava grit on the growth performance, nutrient utilization and carcass characteristics of broiler chickens. International Journal of Agriculture Innovations and Research. Volume 3, Issue.Pp: 1426-1430

SAS, 1999. SAS Users Guide Statistics. SAS Institute Cary, North Carolima, USA.

Steel, R. G. D. and Torrie, J. H. 1990. Principle and procedure of statistics. A Biometrical Approach $3^{\text {rd }}$ Edition. MacGraw
Hill Book Co. New York.

Tewe, O. O. 2005. Ume/Tewe Grit. Federal Repbublic of Nigeria, Patents and Decree 1970 (1970 No. 60), Patent No. RP:16198.

Tuleum, C. D., Njike, M. C., Ikurior, S. A. and Ehidou, N. G. 2005. Replacement of maize with cassava $200 \mathrm{t}$ meal/brewer yeast sherry in the diet of broiler chicks. Proceedings of $30^{\text {th }}$ Annual Conference of Nigeria Society of Animal Production $20^{\text {th }}-24^{\text {th }}$ March 2005 . University of Nigeria. Nsukka. Pp. 183-185.

Zahari, M. W. and Alimon, A. R. 2006. Use of palm kernel cake and oil palm by-products in compound feed. Palm oil development, 40(1): 5-9.

Received: $11^{\text {th }}$ March, 2017

Accepted: $21^{\text {st }}$ July, 2017 